\title{
SIKLUS ADAPTIF, RESILIENSI DAN ISU KEBERLANJUTAN DI SEGARA ANAKAN
}

\author{
Agus Heri Purnomo dan Siti Hajar Suryawati ${ }^{1}$ \\ 1 Peneliti pada Balai Besar Riset Sosial Ekonomi Kelautan dan Perikanan \\ JI. KS. Tubun Petamburan VI, Jakarta 10260 \\ Telp. 021 53650162/Fax. 02153650159
}

\begin{abstract}
ABSTRAK
Laguna Segara Anakan merupakan sebuah ekosistem yang sangat dinamis, dengan interaksi yang kuat antara aspek sosial dan ekologis. Oleh karena itu, laguna tersebut dapat dijadikan kasus acuan yang sempurna bagi kalangan ilmiah maupun pengambil kebijakan dalam rangka merumuskan kebijakan pengelolaan bagi keberlanjutan sumber daya dan lingkungan. Sejalan dengan itu, sebuah penelitian dilaksanakan dengan fokus pada penggambaran interaksi sosial-ekologis dari laguna. Tulisan ini merupakan bagian dari penelitian tersebut, yang dilaksanakan dengan pendekatan sistem sosial-ekologis. Data dikumpulkan pada Bulan Juli-Desember 2009 dengan pendekatan kasus pada 3 (tiga) dusun, terutama melalui wawancara terhadap responden-responden kunci yang ditentukan secara purposif. Dusun-dusun tersebut dipilih berdasarkan keterwakilan dominansi masyarakat di laguna, yaitu masyarakat petani (Dusun Bugel), masyarakat pembudidaya (Dusun Bondan), dan masyarakat campuran (Dusun Lempong Pucung). Secara umum, hasil penelitian ini menunjukkan bahwa melalui siklus adaptif sosialekologi, penyesuaian sosial telah berlangsung mengikuti dinamika ekologis yang ada. Jenis dan struktur mata pencaharian terus berkembang menyesuaikan dengan perubahan lingkungan. Sementara itu, visi masyarakat mengalami perubahan; sebagian dari masyarakat mengalami transformasi dari 'manusia maritim' menjadi 'manusia darat'. Hasil yang diperoleh juga menunjukkan adanya indikasi yang kuat bahwa dalam konteks sosial, perubahan tersebut terjadi sebagai dampak dari perubahan aspek ekologi laguna; produktivitas kelautan menurun, kegiatan di daratan menjadi meningkat. Sejauh ini, teridentifikasi sejumlah pilihan kebijakan, termasuk di antaranya beberapa pendekatan rekayasa fisik dan sosial yang dimaksudkan untuk menghentikan degradasi lingkungan yang berlanjut.
\end{abstract}

Kata kunci: Siklus Adaptif, Resiliensi Masyarakat, Sistem Sosial-ekologis, Keberlanjutan, Segara Anakan

\section{Abstract: Adaptive Cycle, Resilience and Sustainability Issue in Segara Anakan. By: Agus Heri Purnomo and Siti Hajar Suryawati}

Segara Anakan Lagoon represents one of the nation's most rapidly changing natural resource base and environments, and where in ecological dynamics interact intensively with the social aspects. This makes the lagoon a perfect case for the scientific communities and development agents to draw lessons and syntesize policy recommendation related to resource and environmental issues, particularly those pertaining to the frequently raised issue of sustaibable development. In line with it, a study which focuses on portraying the social-ecological interactions of the lagoon is carried out. This paper is a part of the study, presenting a result, which draws upon the social-ecological system methodological approach. Data were collected through a series of survey involving side visits to 3 dusuns and interviews with key respondents from the dusuns, carried out in July to December 2009. The dusuns were selected to represent locations in the lagoon inhabited respectively by predominant farming communities (Dusun Bugel), aquaculture communities (Dusun Bondan), and mixed communities (Dusun Lempong Pucung). In general, the study shows that through social-ecological adaptive cycles, social adjustments have been taking place following the existing ecological dynamics. Livelihood types and structure are constantly developing to adjust to the changing environment. Meanwhile, people's visions are no longer the same; part of the communities obviously is transforming from 'maritime people' to 'terrestrial people'. On the other part, the study also shows strong indications that such changes in the social context is starting to impact on the ecological aspect of the lagoon; marine productivity is declining while terrestrial outputs are inreasing. At this stage, we can make it clear that a number of public policy options are available, including some social and physical engineering approaches directed toward stopping further environmental degradation.

Keywords: Adaptive Cycle, Community Resilience, Social-ecological System, Sustainability, Segara Anakan 


\section{PENDAHULUAN}

Masyarakat di wilayah-wilayah pesisir pada umumnya hidup dalam kondisi ekonomi yang kurang berkembang, sehingga sangat berpotensi menimbulkan tekanan besar terhadap sumberdaya dan mengancam keberlanjutan ekologis maupun sosial dan ekonomis. Dalam kaitannya dengan hal ini, resiliensi masyarakat yang tercermin dalam pola-pola adaptasi mereka terhadap gejala dan perubahan alam merupakan sebuah isu sentral yang perlu mendapatkan perhatian besar. Masyarakat dengan resiliensi yang besar akan mengalami dampak yang lebih kecil dari perubahan-perubahan alam yang bersifat negatif, dan begitu sebaliknya, mereka akan memberikan respon lebih baik terhadap perubahan tersebut sehingga kerusakan alam akibat respon tersebut relatif dapat lebih terkendalikan. Untuk itu, upaya pelestarian ekologis maupun sosial harus dikaitkan dengan upaya meningkatkan resiliensi, yang besar kecilnya ditentukan oleh berbagai variabel sosial maupun variabel ekologis dan interaksi di antaranya. Upaya peningkatan resiliensi dalam sistem sosial dimaksudkan untuk menambah kapasitas manusia untuk mengantisipasi dan merencanakan masa depan, yang disebut sebagai kapasitas adaptif. Ini tidak terlepas dari hubungannya dengan aspek ekologis, sehingga untuk itu diperlukan pemahaman yang baik mengenai sistem kompleks yang menghubungkan ilmu sosial dan ilmu biofisik (Mclntosh et al., 2000; Kasperson et al., 1995; Berkes and Folke, 1998; Scoones, 1999; Gunderson dan Holling, 2002; Berkes et al., 2002).

Masyarakat Segara Anakan beserta lingkungan di sekitarnya mempunyai ciri-ciri sosio-biogeofisik yang sangat kompleks, sehingga dapat dijadikan referensi untuk memahami fenomena kerusakan, interaksi antara manusia dan alam serta isu keberlanjutan pada sistem-sistem sosial ekologis lain. Kawasan tersebut memiliki potensi sumberdaya yang besar untuk menjamin keberlangsungan hubungan timbal balik antara ekosistem daratan, ekosistem estuari dan ekosistem lautan secara serasi, selaras dan seimbang sebagai habitat flora dan fauna langka. Kawasan tersebut merupakan daerah migrasi berbagai jenis satwa yang dilindungi, daerah asuhan berbagai jenis udang dan ikan bernilai ekonomi tinggi. Selanjutnya, kawasan tersebut juga merupakan sumber penghidupan bagi masyarakat luas. Oleh karena itu, sangat dapat dipahami bahwa oleh pemerintah, Segara Anakan diposisikan sebagai sumberdaya alam yang dapat menjadi modal dasar bagi pembangunan daerah, regional dan nasional sehingga perlu dilestarikan kondisi lingkungannya. Namun demikian, Segara Anakan menghadapi banyak permasalahan di berbagai aspek. Berbagai permasalahan dalam aspek-aspek sosial ekonomi penduduk di sekitar Segara Anakan terjadi akibat proses ekologis yang terjadi di Segara Anakan (Anonim, 2007). Konflik lahan, kompetisi ekonomi, penebangan liar, alih fungsi lahan adalah beberapa di antara masalah sosial ekonomi tersebut. Perubahan ekosistem laut menjadi ekosistem darat menyebabkan perubahan pada pola pencaharian dari aktivitas penangkapan ikan tradisional menjadi aktivitas di bidang pertanian ataupun industri.

Berdasarkan latar belakang di atas, penelitian ini dimaksudkan untuk melakukan pendalaman dan merekonstruksi proses interaksi antara manusia dan alam di Segara Anakan dan mengidentifikasi peran dari aspek sosial dalam interaksi tersebut, terutama dalam dalam hubungannya dengan isu keberlanjutan.

\section{METODOLOGI}

\section{Pendekatan}

Penelitian ini menggunakan pendekatan sistem sosial-ekologis (Folke, 1998; Carpenter and Folke, 2006; dan Anderies et al., 2004). Menurut Folke (1998) dan Carpenter and Folke (2006), sistem sosial-ekologis didefinisikan sebagai sistem yang terpadu dari 
alam dan manusia dengan hubungan yang timbal balik. Sementara itu, menurut Anderies et al., (2004), sistem sosial-ekologis adalah sebuah sistem dari unit biologi/ekosistem dihubungkan dengan dan dipengaruhi oleh satu atau lebih sistem sosial.

Dalam kerangka sistem sosial-ekologis tersebut, resiliensi masyarakat yang tercermin dalam siklus pembaruan adaptif di lokasi penelitian diidentifikasi untuk melakukan deduksi. Mengacu pada Holling (2000), resiliensi dalam penelitian ini dimaksudkan sebagai manifestasi kompleks adaptif pada skala temporal dan spasial, yang mengantar kepada sebuah siklus berulang. Siklus tersebut (Gambar 1) mencakup empat fase perkembangan kejadian dan proses: periode perubahan eksponensial (eksploitasi atau fase $r$ ), periode pertumbuhan statis dan kaku ( konservasi a ta u fase $\mathrm{K}$ ), periode pengaturan ulang dan kehancuran (pelepasan atau fase), serta periode reorganisasi dan pembaruan (fase ).

Pada fase-r (pertumbuhan) pada siklus adaptif, modal dan potensi sumber daya dikerahkan. Kemudian, pada fase-K organisasi dan konektivitas internal dioptimalkan untuk melestarikan modal atau sumberdaya. Dalam siklusnya, fase $\mathrm{K}$ diikuti dengan fase- $\Omega$ yang di dalamnya terjadi kerugian modal atau sumber daya, dan fase-a yang di dalamnya mengandung proses reorganisasi. Melalui penggambaran siklus adaptif, antisipasi dan intervensi dalam rangka untuk mencapai tujuan-tujuan sosial, termasuk keberlanjutan dapat diidentifikasi (Gunderson dan Holling, 2002).

\section{Pengumpulan dan Analisis Data}

Penelitian dilakukan pada tahun 2009 selama lebih kurang enam bulan yaitu dari Bulan Juli s/d Desember 2009. Data utama mengenai resiliensi sosial-ekologi masyarakat dan kronologi kejadian sosial-ekologis di Laguna Segara Anakan dikumpulkan dalam bentuk data primer. Data pendukung dalam bentuk data sekunder dikumpulkan dari berbagai laporan maupun hasil riset terdahulu yang relevan. Pengumpulan data primer dilakukan dengan menggunaan teknik survei, sementara itu data sekunder akan dikumpulkan dari kepustakaan berbagai lembaga penelitian. Wawancara dikonsentrasikan di 3 dusun yang masing-

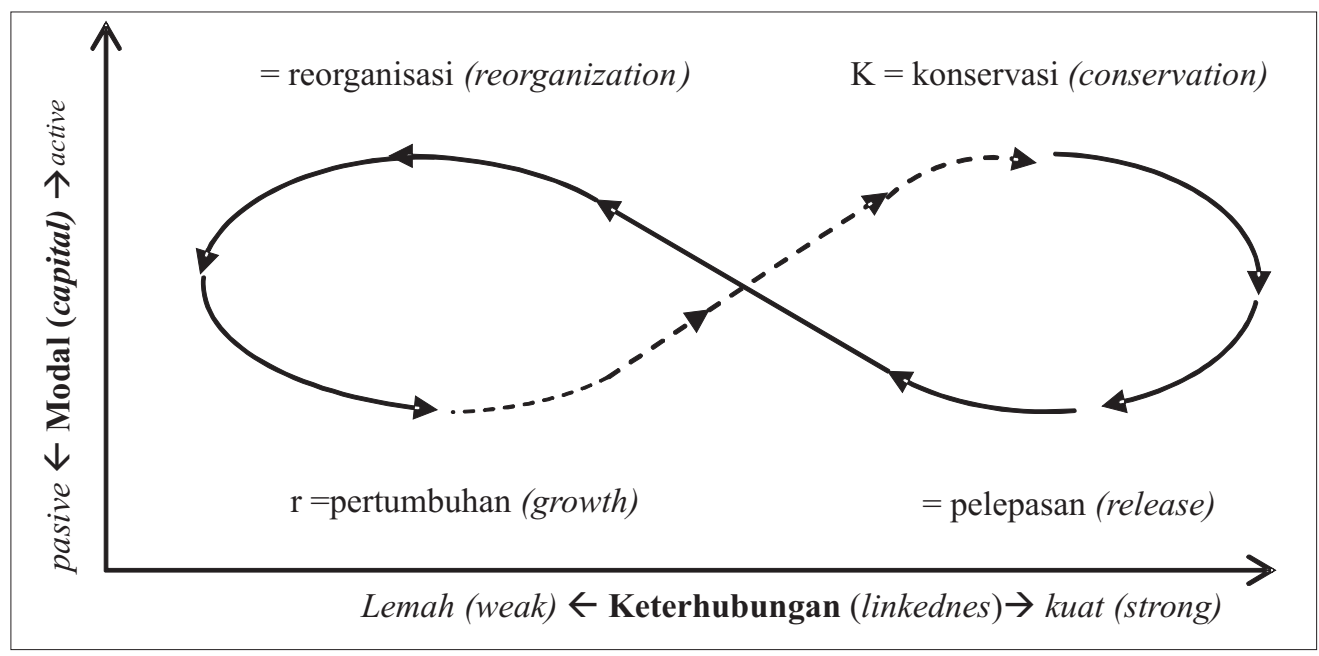

Gambar 1.Siklus Adaptif Empat Fungsi (Diadaptasi dari Holling et al., 2000) Figure 1. Adaptive Cycle of The Four Functions (Adapted from Holling et al., 2000) 
masing dipilih untuk mewakili dusun dengan masyarakat mayoritas petani (Dusun Bugel), masyarakat pembudidaya (Dusun Bondan), dan masyarakat heterogen (Dusun Lempong Pucung). Di setiap dusun tersebut, responden mencakup kepala dusun dan 15-20 anggota masyarakat untuk mewakili berbagai jenis pekerjaan yang ada di dusun-dusun tersebut. Hasil dari penggalian data tersebut kemudian diklarifikasi dan divalidasi melalui diskusi kelompok fokus.

Untuk mencapai tujuan penelitian seperti yang telah diuraikan pada bagian pendahuluan, pengumpulan dan analisis data yang dilakukan dalam penelitian ini dilaksanakan dalam tahapan analisis seperti terangkum pada Tabel 1 .

\section{HASIL DAN PEMBAHASAN}

\section{Identifikasi Sistem Sosial-ekologis di Segara Anakan}

Mengacu pada konsep sebagaimana dijelaskan pada bagian metodologi, sistem sosial-ekologis di Segara Anakan dapat dimodelkan seperti pada Gambar 2. Dalam model tersebut, empat komponen pembentuk sistem adalah: sumberdaya dalam bentuk laguna, pengguna adalah masyarakat Kampung Laut, berbagai bentuk prasarana dan penyedia prasarana.

Berdasarkan hasil identifikasi, Laguna Segara Anakan terdiri dari sub-komponen utama yaitu: (A) badan air, (B) hutan mangrove, dan (C) lahan ekonomi darat. Laguna tersebut dimanfaatkan oleh berbagai kelompok pelaku ekonomi, baik yang bertumpu pada badan air, hutan ekonomi, lahan darat, maupun kombinasi di antaranya. Pengguna-pengguna utama tersebut adalah: (a) nelayan, yang terdiri dari nelayan jaring apong, nelayan penjala, nelayan pencari kepiting dan nelayan pengumpul kerang; (b) petani, yang terdiri dari petani sawah tadah hujan, petani tambak dan pembudidaya kepiting; dan (c) pekerja / penyedia Jasa, yang terdiri dari buruh tani, usaha gula kelapa, dan pencari kayu bakar.
Untuk kegiatan ekonomi dan sosial di dalam laguna tersebut, teridentifikasi berbagai penyedia prasarana umum. Penyediapenyedia prasarana utama tersebut meliputi: (1) Pemerintah pusat, yang terutamanya terdiri dari Kementerian Lingkungan Hidup, Departemem Kelautan dan Perikanan, Departemen Kehakiman, dan Departemen Kehutanan, (2) Pemerintah daerah, yang terdiri Pemerintah Kabupaten, KPSKSA, LP Nusakambangan, dan Perhutani, dan (3) Berbagai Lembaga Swadaya Masyarakat. Bentuk-bentuk prasarana yang tersedia adalah: (i) Prasarana penyediaan air bersih, (ii) Prasarana penerangan, (iii) Prasarana pendidikan, (iv) Prasarana kesehatan dan (v) Prasarana transportasi.

Keempat komponen utama tersebut terikat dalam interaksi-interaksi sebagai berikut:

1. Hubungan antara laguna dan masyarakat.

Deskripsi: berbagai kegiatan sosial maupun ekonomi masyarakat dengan berbagai bentuk profesi sangat tergantung pada keberadaan laguna, baik badan air maupun bagian daratannya. Sebaliknya, kondisi dan dinamika laguna sangat dipegaruhi oleh berbagai kegiatan masyarakat tersebut; misalnya, luasan mangrove sangat ditentukan oleh intensitas kegiatan pembuat kayu bakar, sementara itu sumberdaya perairan dipengaruhi oleh jenis alat, frekuensi dan kapasitas perikanan dimiliki oleh nelayan, dan sebagainya.

2. Hubungan antara masyarakat dan penyedia prasarana.

Deskripsi: keberadaan prasarana yang dipasok secara langsung maupun tidak langsung untuk kepentingan masyarakat terbukti membantu meningkatkan kondisi sosial ekonomi masyarakat, baik penduduk asli maupun pendatang. Namun demikian, keberadaan aktivitas dan sikap tertentu dari sebagian masyarakat tidak cukup mendukung keberlanjutan keberadaan prasarana- 
Tabel1. Tujuan, Lingkup Data, Jenis Data, Metode Analisis dan Keluaran Tahapan Penelitian.

Table 1. Objective, Scope of Data, Kind of Data, Method of Analyses and Output of the Research Steps.

\begin{tabular}{|c|c|c|c|c|c|}
\hline No & $\begin{array}{l}\text { Tujuan / } \\
\text { Objective }\end{array}$ & $\begin{array}{c}\text { Lingkup \& } \\
\text { sumber data/ } \\
\text { Scope\& data } \\
\text { source }\end{array}$ & $\begin{array}{l}\text { Jenis data/ } \\
\text { Kind of data }\end{array}$ & $\begin{array}{l}\text { Metode } \\
\text { Analisis/ } \\
\text { Method of } \\
\text { analyses }\end{array}$ & $\begin{array}{c}\text { Output yang } \\
\text { diharapkan/ } \\
\text { Expected output }\end{array}$ \\
\hline 1 & $\begin{array}{l}\text { Mengidentifikasi } \\
\text { sistem sosial- } \\
\text { ekologis di Segara } \\
\text { Anakan/ } \\
\text { Identification of } \\
\text { social-ecological } \\
\text { system in Segara } \\
\text { Anakan lagoon }\end{array}$ & $\begin{array}{l}\text { - Responden di } \\
\text { Segara Anakan/ } \\
\text { Respondents in } \\
\text { Segara Anakan } \\
\text { lagoon. } \\
\text { - Survel \& studi } \\
\text { pustaka / Survey } \\
\text { and literature } \\
\text { study }\end{array}$ & $\begin{array}{l}\text { - Dimensi sosial- } \\
\text { ekonomi /Social- } \\
\text { economic } \\
\text { dimension } \\
\text { - Dimensi ekologi/ } \\
\text { Ecological } \\
\text { dimension }\end{array}$ & $\begin{array}{l}\text { - Deskriptif/ } \\
\text { descriptive } \\
\text { - Matriks dan } \\
\text { tabulasi/ } \\
\text { Matriks and } \\
\text { tabulation }\end{array}$ & $\begin{array}{l}\text { Representasi grafis } \\
\text { dan deskriptif sistem } \\
\text { sosial-ekologis di } \\
\text { Segara Anakan/ } \\
\text { Graphical } \\
\text { representation and } \\
\text { description of social- } \\
\text { ecological system in } \\
\text { Segara Anakan } \\
\text { lagoon }\end{array}$ \\
\hline 2 & $\begin{array}{l}\text { Mengkaji elemen- } \\
\text { elemen resiliensi } \\
\text { masyarakat dalam } \\
\text { kerangka sistem } \\
\text { sosial ekologis di } \\
\text { Segara Anakan/ } \\
\text { Assessing } \\
\text { community resilience } \\
\text { elements within the } \\
\text { Segara Anakan } \\
\text { social-ecological } \\
\text { framework }\end{array}$ & $\begin{array}{l}\text { - Responden di } \\
\text { Dusun } \\
\text { Bugel,Bondan, } \\
\text { dan Lempong } \\
\text { Pucung/ } \\
\text { Respondent in } \\
\text { Bugel, Bondan } \\
\text { and Lempong } \\
\text { Pucung } \\
\text { - Survei \& FGD/ } \\
\text { Survey and } \\
\text { Focus Group } \\
\text { Discussion }\end{array}$ & $\begin{array}{l}\text { Parameter dan } \\
\text { variabel model } \\
\text { resiliensi ekologi } \\
\text { Segara Anakan/ } \\
\text { Parameters and } \\
\text { variables of Segara } \\
\text { Anakan ecological } \\
\text { resilience model }\end{array}$ & $\begin{array}{l}\text { - Deskriptif/ } \\
\text { Descriptive } \\
\text { - Matriks dan } \\
\text { tabulasi/ } \\
\text { Matrix and } \\
\text { tabulation }\end{array}$ & $\begin{array}{l}\text { Gambaran resiliensi } \\
\text { masyarakat di dalam } \\
\text { sistem sosial- } \\
\text { ekologis di Segara } \\
\text { Anakan / Description } \\
\text { of community } \\
\text { resilience in the } \\
\text { Segara Anakan } \\
\text { social-ecological } \\
\text { system }\end{array}$ \\
\hline 3 & $\begin{array}{l}\text { Merekonstruksi } \\
\text { siklus adaptif sosial- } \\
\text { ekologis di Segara } \\
\text { Anakan/ } \\
\text { Reconstruction of } \\
\text { Segara Anakan } \\
\text { social-ecological } \\
\text { adaptive cycle }\end{array}$ & $\begin{array}{l}\text { - Studi Pustaka/ } \\
\text { Literature study } \\
\text { - Responden pakar/ } \\
\text { Expert respondent }\end{array}$ & $\begin{array}{l}\text { Catatan kejadian } \\
\text { sosial \& ekologis/ } \\
\text { Note on social and } \\
\text { ecological events }\end{array}$ & $\begin{array}{l}\text { - Matriks dan } \\
\text { grafik/ } \\
\text { Matriks and } \\
\text { graphics } \\
\text { - Deskriptif/ } \\
\text { descriptive }\end{array}$ & $\begin{array}{l}\text { Representasi grafis } \\
\text { kronologi adaptasi } \\
\text { sosial-ekologi Segara } \\
\text { Anakan /Graphical \& } \\
\text { chronological } \\
\text { representation of } \\
\text { social-ecological } \\
\text { adaption }\end{array}$ \\
\hline 4 & $\begin{array}{l}\text { Interpretasi } \\
\text { keterkaitan elemen } \\
\text { resiliensi, siklus } \\
\text { adaptif \& } \\
\text { keberlanjutan/ } \\
\text { Interpretation } \\
\text { linkage of resilience } \\
\text { element, adaptive } \\
\text { cycle and } \\
\text { sustainability }\end{array}$ & $\begin{array}{l}\text { Data terolah dari } \\
\text { hasil sebelumnya/ } \\
\text { Data processes }\end{array}$ & $\begin{array}{l}\text { Gambaran SES, } \\
\text { resiliensi dan siklus } \\
\text { adaptasi di Segara } \\
\text { Anakan/ } \\
\text { Description of } \\
\text { Social-Ecological } \\
\text { System, resilience } \\
\text { and adaptation } \\
\text { cycle in Segara } \\
\text { Anakan lagoon }\end{array}$ & $\begin{array}{l}\text { Desk study \& } \\
\text { discussion }\end{array}$ & $\begin{array}{l}\text { Kesimpulan- } \\
\text { kesimpulan/ } \\
\text { Conclusions }\end{array}$ \\
\hline
\end{tabular}

prasarana tersebut. Sebagai contoh, saat layanan prasarana pengadaan air bersih terhenti pada suatu periode karena kendala teknis, kerusakan lebih parah justru terjadi akibat tindakan masyarakat yang terdorong oleh motivasi keuntungan jangka pendek.

3. Hubungan antara penyedia prasarana dengan prasarana.

Deskripsi: keberadaan sebagian 


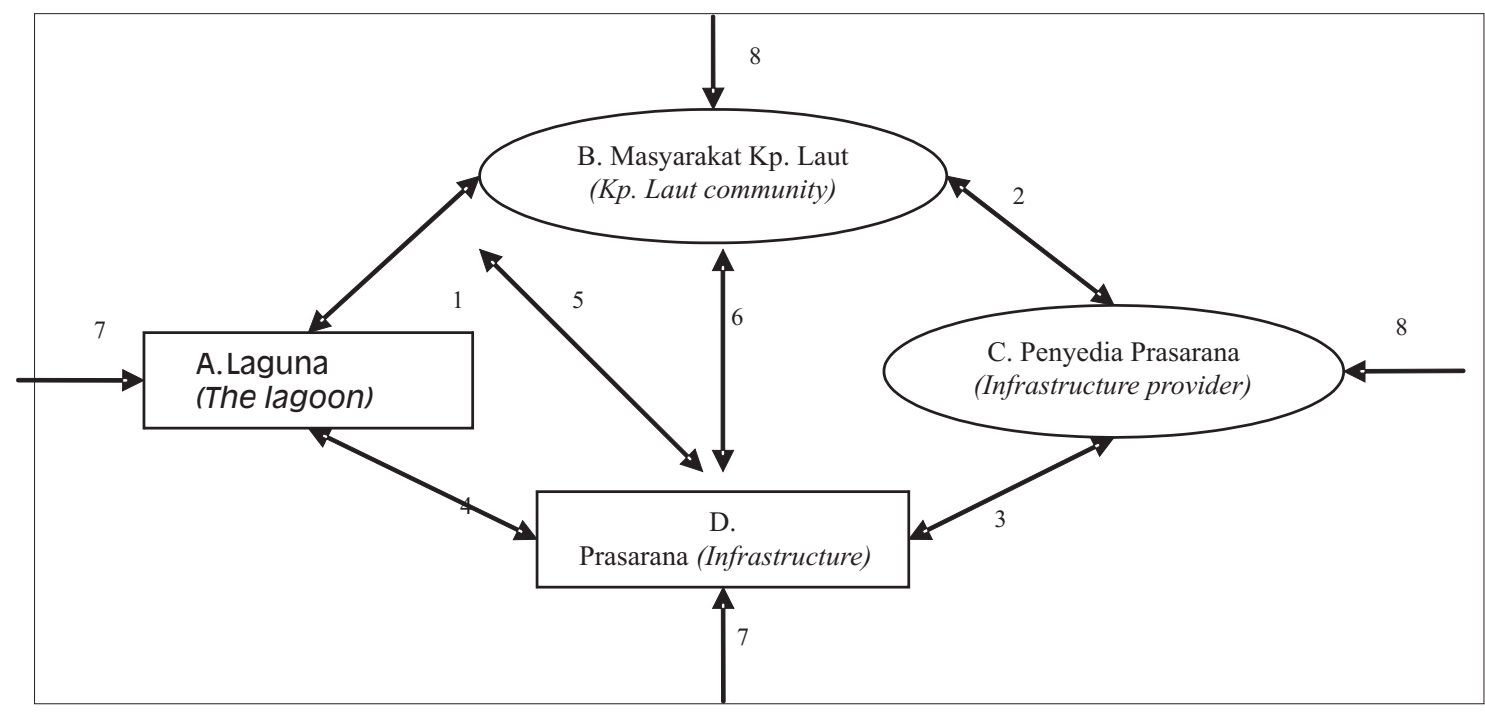

\section{Gambar 2. Model Sistem Sosial Ekologis Segara Anakan (dikembangkan dari Ostrom,} 2006).

Figure 2. Social Ecological System Model of Segara Anakan (Developed from Ostrom, 2006).

prasarana terjadi karena penyedia prasarana memerankan fungsi layanan publik sedangkan sebagian terjadi karena adanya misi tertentu yang menjadi tujuan organisasi penyedia prasarana, misalnya misi keagamaan. Namun demikian, kemunculan penyedia-penyedia prasarana tersebut pada umumnya merupakan respons terhadap ketidaktersediaan (kebutuhan) maupun ketersediaan prasarana yang telah wujud sebelumnya.

4. Hubungan antara laguna dengan prasarana.

Deskripsi: perkembangan kondisi laguna telah menjadi dasar bagi pengadaan berbagai bentuk prasarana; sebagai contoh, penyempitan badan air dan peluasan daratan mendorong penyedia laguna untuk membangun prasarana (dan sarana) sosial dan ekonomi yang memberikan ruang lebih besar kepada masyarakat untuk menyesuaikan diri dengan kondisi laguna yang tidak lagi sama dengan kondisi pada waktu-waktu sebelumnya. Keberadaan prasaranaprasarana baru tersebut, selanjutnya berdampak pada dorongan yang lebih besar terhadap masyarakat untuk merubah perilaku ekonomi, dari yang lebih bertumpu pada pekerjaanpekerjaan darat, sehingga berpotensi mengikis kepedulian pada kelestarian laguna.

5. Hubungan antara prasarana dengan interaksi antara masyarakat dan pengguna sumberdaya.

Deskripsi: peningkatan prasarana menentukan pilihan masyarakat dalam pemanfaatan laguna, sebaliknya dinamika hubungan antara laguna dengan penggunanya, sebagaimana dideskripsikan pada pola hubungan (3), menentukan bentuk-bentuk prasarana yang diadakan oleh penyedia.

6. Hubungan antara masyarakat dengan prasarana.

Deskripsi: ketersediaan prasarana yang lebih mencukupi terbukti mampu memperbesar peluang masyarakat untuk 
meningkatkan kesejahteraannya; sebagai contoh, perbaikan sarana transportasi telah mendorong kreativitas masyarakat untuk melakukan kegiatan produksi dan pemasaran produk-produk andalan lokal (misalnya gula kelapa) ke target-target di luar wilayah mereka.

7. Pengaruh eksternal terhadap prasarana. Deskripsi: Penetrasi informasi dari luar wilayah telah menciptakan kebutuhan yang lebih besar di antara masyarakat akan berbagai prasarana yang dianggap dapat memfasilitasi masyarakat Segara Anakan mendekat kearah gaya hidup di luar wilayah. Sebagaimana dicontohkan dalam wawancara, terungkap bahwa saat pengaruh dari luar telah membuat masyarakat merasa jenuh dengan gaya hidup tertutup dan gaya hidup 'manusia perairan' yang selama ini mereka jalani. Prasarana yang kemudian segera dirasakan sebagai kebutuhan besar dan mendesak adalah misalnya prasarana informasi, transportasi dan keenergian. Dalam beberapa kasus, masyarakat berupaya memperbaiki dan mencari sarana-prasarana untuk lebih meningkatkan kualitas hidupnya. Contoh kasus, dorongan urgensi tak terbendung tersebut bahkan direspon dengan kegiatan pengadaan prasarana secara swadaya; misal, di Dusun Bondan, masyarakat membangun instalasi keenergian secara swadaya meskipun terdapat berbagai kebutuhan primer lain yang belum terpenuhi.

8. Pengaruh eksternal terhadap penyedia prasarana.

Deskripsi: sejauh ini, pengaruh eksternal terhadap kemunculan penyedia prasarana tidak terlalu signifikan. Penyedia prasarana yang ada sejauh ini pada umumnya merupakan penyedia prasarana yang berkewajiban melaksanakan fungsi pelayanan (pemerintah pusat maupun daerah), dengan hanya sedikit penyedia prasarana yang muncul akibat dorongan eksternal.

\section{Elemen-elemen Resiliensi di Segara Anakan}

Mengacu pada batasan-batasan elemen resiliensi (Folke et al., 2002; Walker and Salt, 2006; Krasny and Tidball, 2009), kondisi resiliensi masyarakat di Segara Anakan dapat digambarkan seperti terangkum pada Tabel 2 . Penggambaran tersebut mencakup 5 (lima) kelompok aspek, yaitu pembelajaran adaptif dan sosial, keberagaman, pengorganisasian diri, layanan ekosisitem, dan modal sosial. Secara umum, penggambaran tersebut merefleksikan kondisi masyarakat yang tidak memiliki tingkat resiliensi yang tinggi, karena berbagai sebab. Hal-hal mendasar yang terkait dengan sejarah masyarakat Segara Anakan dan keterisolasian dapat diduga menjadi penyebab dari rendahnya kondisi elemen-elemen resiliensi.

Kenyataan bahwa penduduk pertama masyarakat Segara Anakan merupakan keturunan prajurit Kerajaan Mataram yang ditugaskan untuk menjaga sebuah kawasan perbatasan dari setiap orang asing pada waktu itu menumbuhkan kepribadian yang relatif tertutup (Toro, pers. com: 2009). Hal ini tercermin dari survei kepada responden seperti tertuang dalam pendeskripsian elemen 'modal sosial" (Tabel 2), yang terkait dengan budaya produktif. Ketertutupan ini bahkan telah menyebabkan persepsi yang salah mengenai gejala alam yang sedang terjadi dan keberlanjutan kehidupan sosial-ekonomi mereka; sebagian besar masyarakat mempertahankan pesan pendahulu mereka bahwa kesejahteraan akan terwujud sejalan dengan lenyapnya laguna dan menyatunya tempat tinggal mereka dengan daratan.

Keterisolasian geografis semakin menghambat pengembangan keterbukaan pada masyarakat Segara Anakan. Gambaran kondisi prasarana dan keterkaitannya dengan berbagai komponen sistem sosial ekologis lain di Segara Anakan (Gambar 2 dan 
Tabel 2. Deskripsi Elemen- Elemen Resiliensi di Segara Anakan.

Table 2. Descriptions of Resilience Elements in the Segara Anakan.

\begin{tabular}{|c|c|c|}
\hline & Kondisi /Condition & Keterangan /Remark \\
\hline Persepsi /Perception & $\begin{array}{l}\text { Terdapat persepsi salah } \\
\text { menuju perilaku } \\
\text { kontraproduktif /There is a } \\
\text { false perception leading } \\
\text { to contraproductive } \\
\text { attitudes }\end{array}$ & $\begin{array}{l}\text { - Masyarakat tidak peduli degradasi laguna } \\
\text { /People ignorant about lagoon degradation } \\
\text { - Penangkapan destruktif diterima } \\
\text { (Misalnya jaring apung) / } \\
\text { Destructive fishing method is acceptable } \\
\text { (e.g. apong net) }\end{array}$ \\
\hline Pendidikan / Education & $\begin{array}{l}\text { Tingkat pendidikan rendah/ } \\
\text { Educational achievement } \\
\text { is low }\end{array}$ & $\begin{array}{l}\text { Apresiasi terhadap pengelolaan rendah/ } \\
\text { Appreciation about management is low } \\
\text { Pendidikan rata-rata tamat SD/Average } \\
\text { education only finished elementaryschool }\end{array}$ \\
\hline $\begin{array}{l}\text { Keragaman pencaharian/ } \\
\text { Livelihood diversity }\end{array}$ & $\begin{array}{l}\text { Pilihan mata pencaharian } \\
\text { terbatas / Livelihood } \\
\text { alternatives are limited to } \\
\text { resource extraction }\end{array}$ & $\begin{array}{l}\text { - Pertanian non-irigasi /Non-irrigated farming } \\
\text { - Perikanan tradisional /traditional fishing } \\
\text { - Penebangan bakau /Magrove for firewood } \\
\text { - Pembuatan gula / Making coconut sugar }\end{array}$ \\
\hline $\begin{array}{l}\text { Keragaman lain /Other } \\
\text { diversity }\end{array}$ & $\begin{array}{l}\text { Keragaman budaya / } \\
\text { Cultural diversity }\end{array}$ & $\begin{array}{l}\text { Ada heterogenitas tetapi kurang berbaur/ } \\
\text { Heterogenity exist. but with little interaction } \\
\text { between comers and first communities }\end{array}$ \\
\hline
\end{tabular}

\section{ii. Pengorganisasian diri / Selforganization}

Keterlibatan dalam organisasi masyarakat/ Involvement in community organization

Partisipasi dalam pengambilan keputusan/ Participation in community decision making

Migrasi /Migration

Organisasi hanya milik sebagian orang/ Organization belongs to only few villagers

Partisipasi hanya milik sebagian orang /Similar to the case of organization

Inmigrasi > outmigrasi / In-migration > outmigration

\section{iii. Layanan ekosistem /Ecosystem services}

Institusi formal dalam pengelolaan sumberdaya/ Formal institution in resource management Institusi informal pengelolaan sumberdaya/ Informal institution in resource management

Ada kelembagaan formal tapi tidak efektif /Formal institution exists but not effective

Ada kelembagaan formal, yang sporadis /Sporadic informal institution exists
Hanya yang berpendidikan / Only relatively more educated people are normally involved

Hanya yang berpendidikan /Only relatively more educated people are normally involved

\section{iv. Modal sosial/Social capital}

Budaya produktif/

Productive culture

Kepercayaan di antara penduduk /Trusts among villagers Manajemen konflik /Conflict management
Masyarakat tertutup, tapi produktif /People are closed minded but hard workers

Kecurangan merupakan tabu /Cheating, is a big taboo

Konflik diselesaikan secara adat /Disputes are usually settled following a traditional mechanism
- Larangan Jaring Apung/Prohibition of apong net (Perda No 6/2001)

- BPKSA / The Lagoon Mg Authority

- Serifikasi lahan /Farm land certification

Beberapa orang membuat kelompok konservasi laguna / A few people established a lagoon conservation group

Saat mereka telah teryakinkan, mereka akan bersungguh2/People are not quickly accept an idea from outsider, but when it happens they will consistently adopt it

Barang pinjaman selalu kembali /Never that borrowed goods or money is not returned to the lenders

Tetua kampung merupakan pilar penyelesaian/ Village elders with adequate past knowledges are the pillar of conflict resolution 
penjelasannya) mengindikasikan adanya hubungan antara keterisolasian wilayah Segara Anakan dengan kondisi prasarana yang ada. Keterkaitan ini dapat dibuktikan dengan adanya perkembangan prasarana secara relatif lebih signifikan di wilayahwilayah Segara Anakan yang telah terbebas dari isolasi geografis dengan daratan Pulau Jawa, yaitu Dusun Bugel di Desa Panikel. Di dusun tersebut, berbagai prasarana sosial, ekonomi dan pemerintahan dibangun dalam periode yang cukup pendek.

Jejak akibat dari akar budaya dan keterisolasian geografis tersebut kemudian terefleksikan pada elemen-elemen resiliensi yang lain, termasuk di dalamnya: keterbelakangan pendidikan, keragaman budaya dan keterbatasan jenis mata pencaharian. Lebih lanjut, sebagian kecil anggota masyarakat yang berhasil mendapatkan kesempatan untuk mendapatkan pendidikan yang lebih tinggi pada umumnya tidak kembali ke wilayah tersebut. Hal ini terutama karena keterisolasian dan semua kondisi yang diakibatnya dipandang tidak memberikan jaminan bahwa kalangan terdidik tersebut akan mendapatkan penghidupkan yang layak sesuai pendidikan yang telah diselesaikannya. Akibatnya, ketersediaan tenaga terdidik menjadi sangat terbatas. Akibat lebih jauh, beberapa elemen resiliensi lain seperti keterlibatan dalam organisasi dan pengambilan keputusan tercatat pula kurang baik; organisasi masyarakat dan sebagian besar pengambilan keputusan kemasyarakatan didominasi oleh sejumlah kecil kalangan lebih terdidik tersebut.

Secara umum dapat disimpulkan bahwa hampir semua elemen yang ada berkontribusi untuk menyebabkan rendahnya resiliensi masyarakat di Segara Anakan. Sebagian elemen yang tercatat sebagai elemen positif adalah budaya produktif yang cukup tinggi, manajemen konflik dan kepercayaan di antara sesama anggota masyarakat.Namun demikian, elemen-elemen positif tersebut tidak cukup kuat untuk menutup pengaruh dari elemen-elemen yang tercatat negatif. Dominasi dari elemen-elemen negatif ini tercermin pula dalam siklus adaptif sosial ekologis sebagaimana dibahas pada Tabel 2.

\section{Siklus Adaptif di Segara Anakan}

Secara visual, siklus adaptif di Laguna Segara Anakan yang menggambarkan resiliensi sosial-ekologinya sebagaimana siklus adaptif yang dikonsep oleh Holling (1973) dapat dilihat pada Tabel 3. Kurun waktu di antara tahun 1980 hingga dekade terakhir ini merupakan periode yang sempurna untuk menggambarkan hubungan antara kejadiankejadian sosial-ekonomi dan ekologis di Segara Anakan. Alasan utamanya adalah bahwa pada periode tersebut, terdapat rangkaian kejadian ekologis dan sosial yang terjadi melalui proses yang sangat cepat. Rangkaian kejadian tersebut dapat secara jelas mengambarkan hubungan satu kejadian dan kejadian berikutnya yang berlangsung dalam siklus-siklus adaptasi berulang.

Pada Tabel 3, terlihat bahwa berbagai kejadian tersebut berawal dari adanya sebuah letusan gunung berapi (Gunung Galunggung) pada Tahun 1982. Letusan tersebut berdampak besar pada laju sedimentasi pada sungai-sungai yang bermuara di Segara Anakan. Pendangkalan cepat yang memperluas areal daratan terjadi dan membuat masyarakat Segara Anakan untuk mempersiapkan sebuah respon utuk mempertahankan keberlanjutan mereka secara sosial dan ekonomis. Dalam terminologi Holling (2000), periode tersebut dapat digolongkan ke dalam fase reorganisasi. Dengan kondisi resiliensi seperti diuraikan di atas, respon sosial yang diberikan oleh masyarakat adalah mencari alternatif yang paling memungkinkan untuk menutup kerugian akibat menyusutnya areal perikanan. Pada saat itu, respon yang pada akhirnya muncul dari masyarakat Segara Anakan adalah pengembangan pencetakan lahanlahan pertanian di atas tanah timbul yang 
Tabel 3. Siklus Adaptif Sosial-Ekologi Laguna Segara Anakan.

Table 3. Social-Ecological Adaptive Cycle of the Segara Anakan Lagoon.

\begin{tabular}{|c|c|c|c|c|}
\hline \multirow{2}{*}{$\begin{array}{l}\text { Fase Siklus } \\
\text { Adaptif / } \\
\text { Adaptive } \\
\text { Cycle Phase }\end{array}$} & \multicolumn{4}{|c|}{ Periode/Period } \\
\hline & $1980-1985$ & $1986-1990$ & 1991 - 1995 & $1996-2005$ \\
\hline $\begin{array}{l}\text { Fase-r I } \\
\text { Phase-r }\end{array}$ & $\begin{array}{l}\text { Penebangan bakau } \\
\text { \& pemanfaatan } \\
\text { tanah timbul untuk } \\
\text { pertanian 'bawon' / } \\
\text { Mangrove cutting } \\
\text { and utilization of } \\
\text { accreation land for } \\
\text { 'bawon' farming }\end{array}$ & $\begin{array}{l}\text { Penebangan bakau } \\
\text { untuk pertambakan } \\
\text { dan pertanian baru/ } \\
\text { Mangrove cutting } \\
\text { for brackish culture } \\
\text { and new farming }\end{array}$ & $\begin{array}{l}\text { Extensifikasi } \\
\text { pertanian di wilayah } \\
\text { yang telah } \\
\text { tersambung dengan } \\
\text { daratan / Farm } \\
\text { extensification on } \\
\text { areas merged to } \\
\text { mainland }\end{array}$ & $\begin{array}{l}\text { Peningkatan eskalasi } \\
\text { in-migrasi dan } \\
\text { ekonomi di lokasi2 } \\
\text { tertentu / Escalating in- } \\
\text { migration and } \\
\text { economy in } \\
\text { concentrated } \\
\text { locations }\end{array}$ \\
\hline $\begin{array}{l}\text { Fase-K I } \\
\text { Phase-K }\end{array}$ & $\begin{array}{l}\text { Budidaya } \\
\text { tumpangsari untuk } \\
\text { meredam laju } \\
\text { pertanian sawah / } \\
\text { Mixed culture to } \\
\text { reduce rate of farm } \\
\text { extensification }\end{array}$ & $\begin{array}{l}\text { Melokalisir } \\
\text { perkembangan } \\
\text { areal pertambakan/ } \\
\text { Localize the } \\
\text { locations of } \\
\text { brackish culture }\end{array}$ & $\begin{array}{l}\text { Menunda } \\
\text { pembangunan } \\
\text { prasarana untuk } \\
\text { mengendalikan } \\
\text { peluasan pertanian / } \\
\text { Postpone irrigation } \\
\text { infrastructure to } \\
\text { control farm land } \\
\text { extensification }\end{array}$ & $\begin{array}{l}\text { Pengendalian } \\
\text { sertifikasi lahan di } \\
\text { tanah timbul: sertifikasi } \\
\text { hanya diberikan untuk } \\
\text { perumahan, bukan } \\
\text { areal pertanian / } \\
\text { Certification limitation: } \\
\text { to housing, not farming }\end{array}$ \\
\hline $\begin{array}{l}\text { Fase- } \Omega \text { I } \\
\text { Phase- } \Omega\end{array}$ & $\begin{array}{l}\text { Perkembangan } \\
\text { pertanian diteruskan } \\
\text { dengan implikasi } \\
\text { kerusakan yang } \\
\text { sinifikan / Farm } \\
\text { development } \\
\text { continues with } \\
\text { significant envt'l } \\
\text { damage }\end{array}$ & $\begin{array}{l}\text { Pertambakan dan } \\
\text { sawah berkembang } \\
\text { hampir tak } \\
\text { terkendalikan / } \\
\text { Brackish culture } \\
\text { and farming } \\
\text { develop almost } \\
\text { uncontrolably }\end{array}$ & $\begin{array}{l}\text { Pengerukan intensif } \\
\text { untuk mendukung } \\
\text { pertanian terjadi } \\
\text { konflik disposal } \\
\text { kerukan /Dredging is } \\
\text { done to support } \\
\text { farming disposal } \\
\text { conflict }\end{array}$ & $\begin{array}{l}\text { Terjadi jual beli lahan } \\
\text { pertanian dari } \\
\text { penduduk asli ke } \\
\text { pendatang } \\
\text { kepemilikan lahan } \\
\text { produksi menjadi } \\
\text { pincang /Farm land } \\
\text { trade occurs between } \\
\text { villagers \& comers }\end{array}$ \\
\hline $\begin{array}{l}\text { Fase-a / } \\
\text { Phase-a }\end{array}$ & $\begin{array}{l}\text { Konservasi tetap, } \\
\text { tapi prasarana } \\
\text { produksi pertanian } \\
\text { dibenahi /Conservation } \\
\text { continues but } \\
\text { agriculture } \\
\text { infrastructure also is } \\
\text { developed }\end{array}$ & $\begin{array}{l}\text { Pengendalian } \\
\text { kepemilikan lahan / } \\
\text { Land ownership } \\
\text { control }\end{array}$ & $\begin{array}{l}\text { Pengaturan } \\
\text { pembuangan } \\
\text { disposal plus } \\
\text { penataan lokasi } \\
\text { pertanian /Regulate } \\
\text { dregding product } \\
\text { disposal }\end{array}$ & $\begin{array}{l}\text { Fase reorganisasi } \\
\text { belum terjadi / } \\
\text { Reorganization has not } \\
\text { occured }\end{array}$ \\
\hline
\end{tabular}

Sumber: Data Primer/Source: Primary Data

terbentuk oleh proses sedimentasi cepat tersebut. Namun, dengan keterbatasan sumberdaya manusia yang dimiliki oleh masyarakat (Tabel 2 dan penjelasannya), pencetakan lahan-lahan pertanian tersebut dilakukan dengan mengundang petani-petani dari daratan Pulau Jawa dengan beberapa kesepakatan ${ }^{1}$ yang mereka tentukan bersama.

Pada periode berikutnya, terjadi fase pertumbuhan (growth), dimana petani-petani bawon ${ }^{2}$ melakukan kegiatan budidaya padi di lahan-lahan tanah timbul. Hutan-hutan bakau

\footnotetext{
'Kesepakatan di antara masyarakat Segara Anakan dengan petani luar melalui sistem bawon: hak atas bidang sawah yang dimiliki oleh penduduk asli diberikan sebagian kepada petani pendatang sebagai imbalan atas pengerjaan sawah tersebut dan atas 'pelajaran bertani' yang diberikan oleh petani pendatang kepada pemilik hak bidang sawah

${ }^{2}$ Petani bawon adalah petani pendatang (atau dari manapun asalnya) yang mendapatkan upah penggarapan dalam bentuk bagian hasil tertentu
} 
yang berasal dari tanah-tanah yang baru terbentuk maupun yang timbul pada waktuwaktu sebelumnya dikonversi menjadi lahanlahan pertanian, terutama padi. Pada saat itu, terjadi perubahan perilaku masyarakat yang pada umumnya menggantungkan hidupnya pada lahan-lahan perairan, terutama sebagai nelayan. Dengan kondisi yang ada, sebagian besar masyarakat berpendapat bahwa mereka telah menemukan momentum untuk mensejahterakan diri dengan menjadi masyarakat daratan, dengan kemudahan dan aksesibilitas terhadap berbagai sumber kehidupan darat. Dalam situasi seperti itu, jumlah petani pembawon yang masuk dan kemudian berdomisili di wilayah Segara Anakan meningkat tajam, menyebabkan kenaikan populasi secara signifikan. Kenaikan jumlah penduduk ini makin memperberat beban masyarakat setempat karena kompetisi yang meningkat. Sebagian masyarakat menemukan jalan keluar dengan melakukan aktivitas ekonomi yang destruktif termasuk penebangan hutan bakau. Dengan tingkat pendidikan yang pada umumnya rendah, pilihan pekerjaan pun menjadi terbatas; lebih jauh, pendidikan rendah juga membuat masyarakat sulit untuk menerima penyadaran dari luar tentang praktek destruktif. Sebagai contoh, mereka berpendapat bahwa tanaman kayu tancang (Bruguiera $s p$ ) tidak termasuk kategori bakau, dan karenanya tidak dikenakan larangan penebangan.

Secara bersamaan, sedimentasi terus berlangsung dan mengakibatkan penyusutan luasan laguna terus berlanjut, sehingga kegiatan perikanan semakin tidak ekonomis. Sebagian masyarakat dengan pengetahuan relatif lebih baik mengupayakan kelangsungan kehidupan sosial dan ekonominya melalui pengembangan usaha-usaha budidaya, sebagian lainnya mengembangkan perikanan lepas pantai. Namun, pengembangan usahausaha tersebut masih menemui banyak kendala; misalnya, perikanan lepas pantai belum terdukung oleh armada yang mampu dioperasikan pada saat musim ombak karena kapal-kapal penangkap berukuran kecil. Sementara itu, informasi mengenai peluang ekonomi di Segara Anakan meluas ke kalangan lebih luas di wilayah lain sehingga tanah timbul dan hutan bakau secara berlanjut menjadi sasaran masyarakat, tidak hanya penduduk asli melainkan juga para pendatang. Perkembangan ini semakin mempercepat kerusakan ekologis di Segara Anakan.

Dalam perkembangannya, pertanian yang mengandalkan keberadaan tanah timbul terbukti tidak memberikan solusi yang baik kepada masyarakat. Selain karena benefit yang ditimbulkan lebih dinikmati oleh para pendatang, produktivitas pertanian ternyata menurun setelah beberapa tahun kemudian karena beberapa sebab, salah satunya adalah karena irigasi yang terganggu oleh sedimentasi. Pada periode itu, masyarakat berpikir untuk mengurangi kecepatan kerusakan dengan berbagai upaya yang didukung oleh lembaga-lembaga pemerintah maupun non pemerintah. Budidaya tumpangsari yang menggabungkan tujuantujuan ekonomis dan ekologis diperkenalkan di beberapa lokasi. Salah satu contohnya adalah penanaman bakau yang digabungkan dengan budidaya kepiting (Anonim, 2009), yang diharapkan dapat mengembalikan kondisi alam sekaligus memberikan manfaat ekonomis kepada masyarakat. Ini adalah fase konservasi sebagaimana dimaksudkan oleh Holling (2000).

Upaya-upaya konservasi tidak segera menunjukkan hasil yang memuaskan; kondisi tersebut mendorong masyarakat untuk memasuki fase reorganisasi (fase- $\alpha$ ). Pada periode itu, upaya-upaya konservasi masih dijalankan, tetapi pengembangan pertanian kembali digalakkan melalui perbaikan prasarana-prasarananya. Prasarana utama yang endapatkan perhatian adalah prasarana irigasi. Langkah konkret yang kemudian dijalankan adalah mengajukan usulan kepada pemerintah untuk melakukan pengerukan alur sungai atau anak sungai. Pengerukan tersebut 
juga dimaksudkan untuk membuat tanahtanah timbul 'buatan' dalam rangka memperluas areal lahan pertanian, yaitu dengan memanfaatkan tanah hasil pengerukan untuk melakukan penimbunan di lahan-lahan basah.

Fase pertumbuhan (fase-r) kembali berulang. Dengan adanya prasarana irigasi yang lebih baik dan ketersediaan lahan pertanian yang lebih luas, kegiatan pertanian kembali meningkat. Sejalan dengan itu, di bagian lain dari kawasan Segara Anakan berkembang kegiatan-kegiatan produk lain, yang juga dilakukan dengan cara destruktif, yaitu pengembangan tambak udang, yang diawali dengan penebangan hutan bakau, yang dilakukan oleh para pendatang dari lokasi yang lebih jauh, yaitu Propinsi Jawa Barat. Seperti terjadi pada siklus sebelumnya, berbagai permasalahan baru kemudian timbul, termasuk penurunan produktivitas lahan tambak dan marginalisasi ${ }^{3}$ penduduk lokal, yang pada gilirannya mendorong upaya- upaya konservasi. Pada periode itu, upayaupaya konservasi yang terjadi adalah di antaranya melokalisir kawasan pertambakan. Wilayah-wilayah pertambakan tersebut dibatasi oleh batas administratif ${ }^{4}$, dengan harapan bahwa lahan tambak dikembangkan tidak melebihi batas terluas wilayah administratif tersebut.

Pada periode-periode selanjutnya, pola siklus adaptif tidak berubah, yaitu berkembang dengan keterbatasan-keterbatasan yang tidak jauh berbeda. Interaksi sosial-ekologis tidak berubah dan elemen-elemen resiliensi yang ada, berdasarkan hasil wawancara tercatat relatif sama untuk kondisi sekarang dan beberapa dekade sebelumya. Dengan situasi dan kondisi seperti itu, terpantau terjadi perubahan struktur pencaharian, dimana komposisi penduduk yang melakukan pekerjaan berbasis air mengalami penurunan sedang komposisi penduduk yang menggeluti jenis pekerjaan darat mengalami kenaikan sepanjang waktu (Gambar 3).

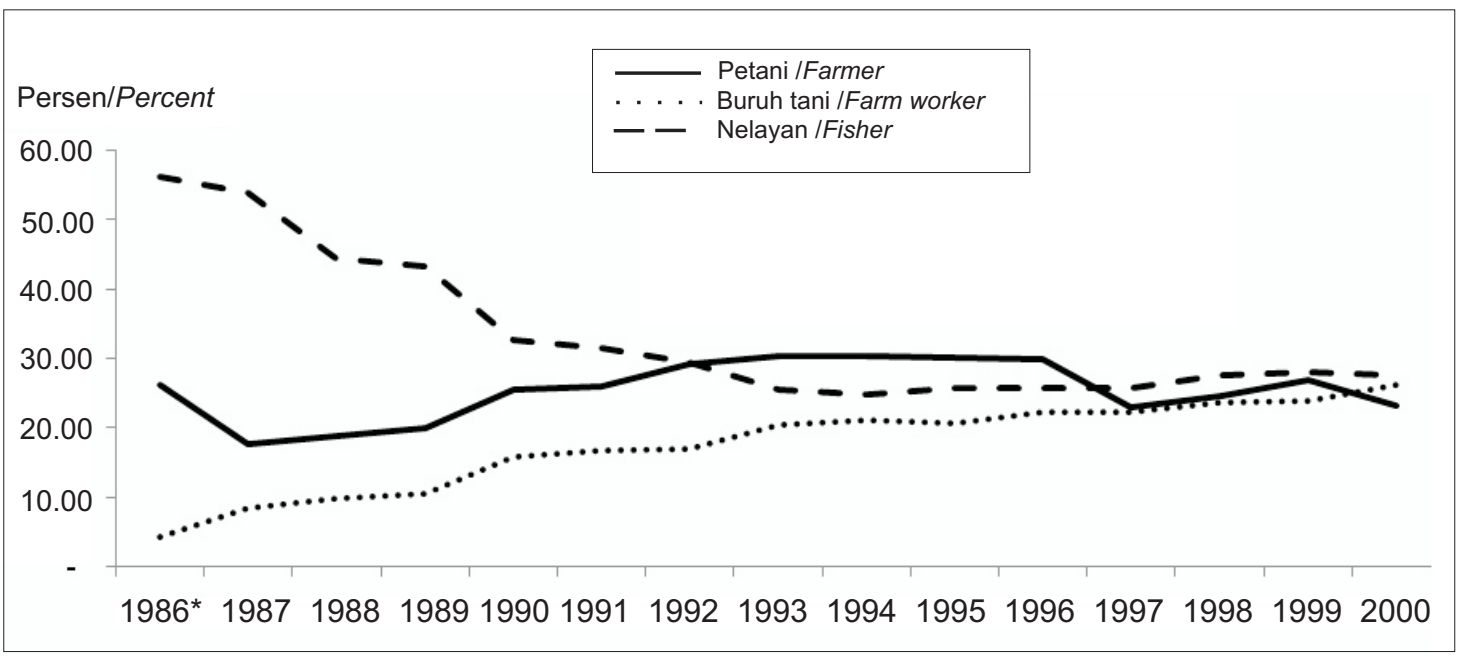

Sumber: Prayitno (2001);Anonim (2005)/Source:Prayitno (2001);Anonim

\section{Gambar 3. Perubahan Prosentase Keterlibatan Penduduk dalam Pencaharian.} Figure 3. Change in Percentage of People Engaged in Various Types of Livelhood. 
Keterkaitan antara sistem sosial ekologis, kondisi elemen resiliensi, siklus adaptasi dan keberlanjutan

Siklus terus berlangsung dan berulang. Secara umum, gejala yang dapat diidentifikasi adalah (1) kondisi masyarakat di Segara Anakan dalam kondisi yang makin tidak sejahtera dan (2) kondisi alam yang semakin terdegradasi. Meskipun kemiskinan ini dapat dikategorikan ke dalam dua penyebab, kemiskinan yang telah ada sebelumnya dan kemiskinan yang terbentuk pada masa-masa kemudian, jelas bahwa dari uraian di atas dapat disimpulkan bahwa kemiskinan tersebut terkait dengan interaksi sosial-ekologis yang mengarah pada semakin besarnya tekanan ekonomi terhadap masyarakat. Dengan pola yang sama, kondisi lingkungan semakin memburuk akibat terbatasnya peluang bagi masyarakat untuk memberikan respon yang lebih baik terhadap dinamika alam.

Keberlanjutan dalam bahaya. Kecenderungan yang ditunjukkan oleh rangkaian siklus adaptif tersebut di atas mengarah pada kesimpulan bahwa sistem sosial ekologis dan kondisi resiliensi yang ada di Segara Anakan, apabila tidak ditangani akan membawa resiko pada keberlanjutan, baik terhadap manusianya maupun alam lingkungan di sekitarnya. Sumberdaya alam pada akhirnya tidak dapat memberikan manfaat kepada manusia dan sebagai akibatnya masyarakat tidak dapat mempertahankan eksistensinya di lokasi tersebut.

Dalam kaitan ini, diskusi di atas menunjukkan bahwa beberapa faktor kunci telah berperan dominan dalam menentukan kecenderungan atau arah perjalanan (trajectory) dari siklus adaptasi tersebut. Faktor-faktor tersebut adalah pendidikan, pertumbuhan penduduk dan proses sedimentasi. Capaian pendidikan pada umumnya sangat rendah; sebagian besar masyarakat di kawasan Segara Anakan hanya menyelesaikan sekolah dasar (Gambar 4) sedangkan penduduk meningkat secara tajam dari tahun ke tahun (Gambar 5).

Apabila salah satu atau gabungan dari faktor-faktor tersebut ditangani dengan baik, peluang akan terbuka bahwa penghidupan masyarakat akan menjadi lebih baik, tekanan

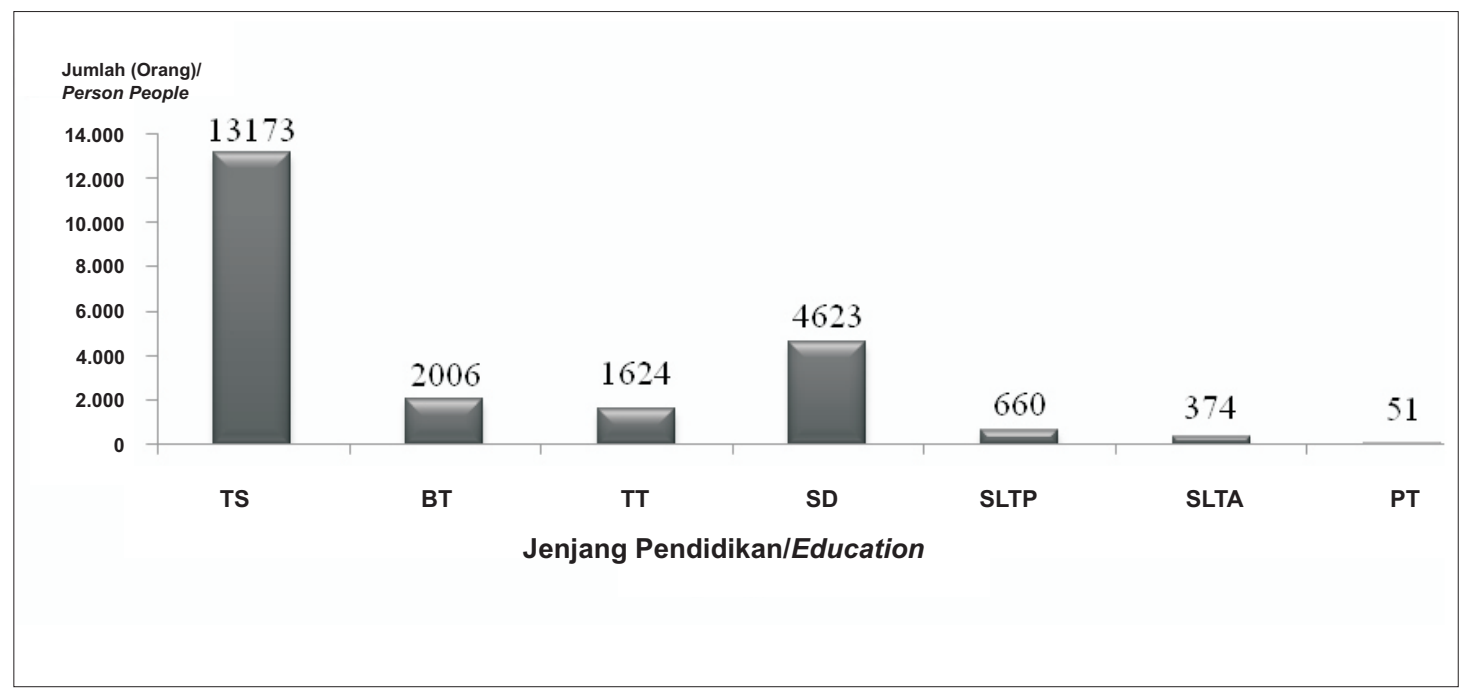

Sumber: Prayitno (2001);Anonim (2005)/Source:Prayitno (2001);Anonim

\section{Gambar 4. Pendidikan Masyarakat Berusia >5 Tahun.}

Figure 4. Education Achievement of People Aged $>5$ Years. 


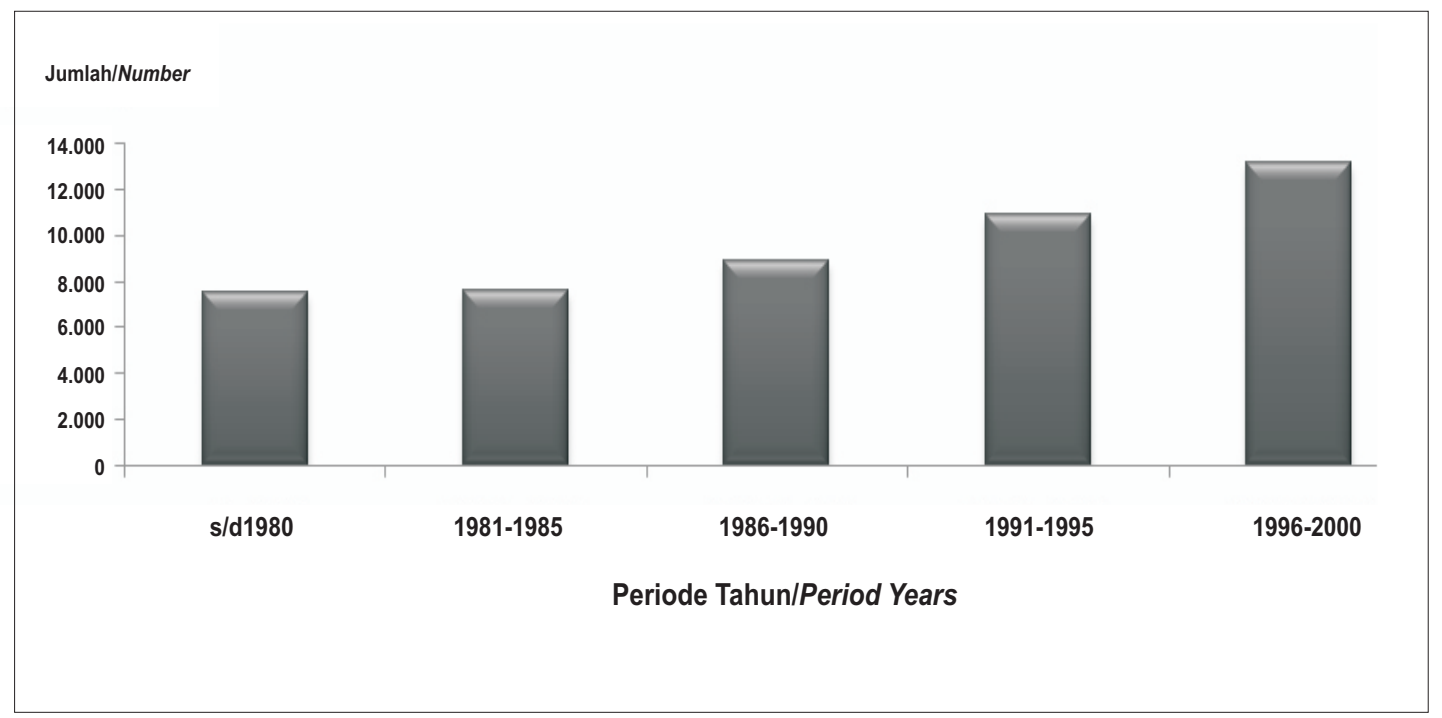

Sumber: Prayitno (2001);Anonim (2005)/Source:Prayitno (2001);Anonim

\section{Gambar 5. Jumlah Penduduk Segara Anakan.}

Figure 5. Number of Population of Segara Anakan.

terhadap alam akan berkurang dan layanan ekologis maupun sosial ekonomis dari alam akan terjaga dari waktu ke waktu. Dari bahasan di atas, dapat diasumsikan bahwa ketiganya akan dapat berperan secara sendirisendiri maupun secara sinergi; sebagai contoh, apabila perkembangan penduduk dapat dikendalikan maka kesempatan maka kompetisi sosial-ekonomi dapat ditekan sehingga dorongan untuk merusak dapat dikurangi. Apabila disinergikan dengan penanganan faktor lain, misalnya perbaikan kondisi sumberdaya manusia, maka upaya pengendalian penduduk akan memberikan efek yang lebih baik, baik dalam hal penciptaan peluang-peluang ekonomi bagi masyarakat maupun dalam hal penurunan kondisi kompetitif yang sifatnya merusak.

Di samping ketiga faktor tersebut di atas, faktor yang juga penting dalam sistem sosial ekologis dan resiliensi masyarakat adalah keberadaan dan kondisi prasarana. Mengacu pada siklus adaptif (Tabel 3), dicontohkan bahwa pada saat dikembangkan upaya-upaya pengakenaragaman usaha, kendala yang teridentifikasi adalah terbatasnya prasarana irigasi yang diperlukan untuk pertanian dan budidaya dan prasarana transportasi yang mendukung rantai produksi dan pemasaran

\section{Perspektif Kebijakan}

Dalam pendekatan konvensional pengelolaan sumberdaya, fase eksploitasi dan konservasi merupakan fokus perhatian sedangkan fase pelepasan dan fase reorganisasi lebih banyak diabaikan. Padahal kedua fase ini, yang dalam resiliensi disebut sebagai 'back-loop', memiliki nilai sangat penting dalam dinamika sistem secara keseluruhan (Gunderson and Holling, 2002; Berkes et al., 2003). Untuk itu, dalam penelitian ini implikasi kebijakan yang akan disarankan dibangun dengan bobot yang cukup pada fase pelepasan dan re-organisasi. Telah dipaparkan sebelumnya bahwa di dalam sistem sosial ekologis dan elemen-elemen resiliensi di Segara Anakan, terdapat beberapa faktor kunci, sehingga dengan demikian penanganan kedua fase tersebut perlu dikaitkan dengan penanganan faktorfaktor kunci tersebut. 
Sesuai dengan permasalahan yang ada sebagaimana telah diungkapkan sebelumnya, pengendalian penduduk merupakan salah satu yang perlu dipertimbangkan, termasuk menekan laju pertambahan penduduk pendatang maupun peningkatan populasi penduduk asli. Untuk itu, beberapa langkah relevan yang perlu dipertimbangkan adalah di antaranya transmigrasi, keluarga berencana dan pengendalian in-migrasi. Transmigrasi merupakan kebijakan yang pernah diterapkan sebelumnya sehingga kebijakan tersebut perlu dipertimbangkan kembali dengan belajar pada keberhasilan dan kegagalan pada penerapan program transmigrasi sebelumnya. Program transmigrasi di waktu lalu berhasil dalam hal meyakinkan penduduk untuk mengikuti program transmigrasi, tetapi gagal karena sejumlah besar peserta transmigrasi tersebut tidak mampu bertahan di lokasi tujuan. Salah satu penyebab kegagalan tersebut adalah bahwa bersamaan dengan perkembangan di lokasi tujuan yang belum signifikan, di Segara Anakan terjadi perkembangan ekonomi baru terkait dengan munculnya tanah-tanah timbul.

Terkait dengan peningkatan kapasitas sumberdaya manusia, terdapat bebagai peluang untuk melaksanakannya. Pada Tabel 2, dapat dilihat bahwa terlepas dari kelemahan yang ada pada sebagian elemen resiliensi masyarakat, terdapat sebuah elemen positif, yaitu dalam hal budaya kerja dan budaya kerjasama. Kedua elemen ini dapat dijadikan titik awal untuk peningkatan kapasitas sumberdaya manusia, terutama dalam hal peningkatan ketrampilan dan pengetahuan informal yang memungkinkan masyarakat beralih atau memiliki pencaharian tambahan yang membawa manfaat langsung pada pendapatan namun tidak merusak lingkungan. Usaha-usaha tumpangsari yang telah diawali di beberapa lokasi dapat dijadikan laboratorium pembelajaran langsung bagi masyarakat.

Pilihan kebijakan lain yang dapat dipertimbangkan adalah menambah kapasitas prasarana pendidikan formal. Animo belajar penduduk Segara Anakan pada umumnya tinggi, namun sarana prasarana pendidikan sangat terbatas. Sebagian penduduk harus berjalan dan menggunakan sarana transportasi air hingga $5 \mathrm{~km}$ untuk mencapai lokasi-lokasi sekolah. Lebih lanjut, sejumlah besar tenaga pengajar di lokasi-lokasi tersebut adalah tenaga sukarela yang berafiliasi ke lembaga swadaya masyarakat. Situasi ini menyiratkan adanya peluang yang besar dari pemerintah sebagai salah satu penyedia prasarana di dalam sistem sosial ekologis Segara Anakan (Gambar 2 dan penjelasannya) untuk meningkatkan perannya.

\section{KESIMPULAN DAN IMPLIKASI KEBIJAKAN}

\section{Kesimpulan}

1. Sistem sosial ekologis Segara Anakan secara umum dalam keadaan terganggu berat, terutama akibat disturbansi eksternal berupa sedimentasi, yang terkait aktivitas di sisi hulu, yang tidak dapat tertahan oleh kondisi fisik maupun sosial yang ada

2. Beberapa faktor penentu yang menyebabkan rendahnya kapasitas SES Segara Anakan untuk menahan disturbansi eksternal tersebut adalah di antaranya adalah populasi, kondisi suberdaya manusia dan prasarana pendukung kegiatan sosial dan ekonomi masyarakat

3. Rumusan model resiliensi sosial-ekologi masyarakat di Laguna Segara Anakan: Resiliensi SES di Segara Anakan dapat ditingkatkan atau menjadi lemah, tegantung pada bentuk intervensi yang diarahkan pada beberapa elemen sosialekonomi, terutama yang yang terkait erat dengan elemen ekologis.

4. Peluang-peluang yang dapat dipertimbangkan untuk meningkatkan kondisi dari elemen-elemen resiliensi di 
Segara Anakan adalah: transmigrasi, pengendalian populasi manusia, pengalihan aliran sungai

5. Tantangan-tantangan utama yang harus menjadi prioritas perhatian untuk mewujudkan berbagai peluang yang ada adalah: rendahnya kualitas sumberdaya manusia dan buruknya kondisi prasarana ekonomi dan sosial

\section{Implikasi Kebijakan}

1. Implikasi kebijakan lokal: pemerintah daerah perlu menfokuskan pada dua hal yaitu pendidikan masyarakat dan pembangunan prasarana ekonomi-sosial

2. Implikasi kebijakan umum: perlu perhatian pada aspek-aspek lokal yang spesifik untuk masing-masing lokasi rawan bencana sebagaimana diindikasikan oleh kasus Laguna Segara Anakan.

\section{DAFTAR PUSTAKA}

Anonimous. 2005. Laporan Mini Survey Sosial Ekonomi Kawasan Segara Anakan. Cilacap. Badan Pengelola Kawasan Segara Anakan . . 2007. Laporan Kegiatan Pengendalian Penduduk dan Penduduk Pendatang di Kawasan Segara Anakan Tahun 2007. Cilacap.

.2009. Budidaya Kepiting di SegarAnakan.http://www.cilacapmedia.c om/ index.php/rubrik/sains-ateknologi/41-sains-a-teknologi/754budidaya-kepiting-di-segara-anakan. Diakses tgl 6 Desember 2009.

Anderies JM, MA Janssen and E Ostrom. 2004. A Framework to Analyze The Robustness of Social-Ecological Systems from An Institutional Perspective. Ecology and Society 9 (1), 18 [online] URL http:// www.ecologyandsociety.org/vol9/iss 1/art 18/.
Berkes, F. 2002. Cross-scale institutional linkages: Perspectives from the bottomup. In Ostrom, E., Dietz, T., Dolsak, N., Stern, P.C., Stonich, S. and Weber, E.U. (eds). The Dramas of the Commons. Washington, D.C. National Academy Press.

Berkes. F, J Colding and C Folke. 2003. Navigating Social-Ecological Systems: Building Resilience for Complexity and Change. Cambridge University Press, Cambridge, UK.

F. and C. Folke, editors 1998. Linking Social and Ecological Systems. Management Practices and Social Mechanisms for Building Resilience. Cambridge University Press, Cambridge, UK.

C. et al (and 24 others). 2002.

Resilience and Sustainable Development: Building Adaptive Capacity in A World of Transformations. Report for the Swedish Environmental Advisory Council 2002:1. Stockholm: Ministry of The Environment. www.mvb.gov.se and also ICSU Series on Science for Sustainable Development No. 3, 2002. Paris: International Council for Science. Gunderson LH and CS Holling. Editors. 2002. Panarchy: Understanding Transformations In Human and Natural Systems. Island Press, Washington DC, USA.

Holling, C. S. 1973 Resilience and Stability of Ecological Systems. Annual Review of Ecology and Systematics. 4050:1-23. .2000. Understanding the complexity of economic, ecological, and social systems. Ecosystems 4(5):390-405.

Kasperson, J. X., R. E. Kasperson, and B. L. Turner. 1995. Regions at risk: comparisons of threatened environments. United Nations University Press, New York, New York, USA.

Krasny ME and KG. Tidball. 2009. SocialEcological System Resilience, Role of Environmental Education. World 
Environmental Education Congress. Montreal, Canada.

Mclntosh RJ, Tainter JA and McIntosh SK.

Editors. 2000. The Way the Wind Blows:

Climate, History and Human Action. Columbia University Press, New York.

Prayitno. 2001. Perubahan Sosial Ekonomi

Masyarakat Pantai akibat Perubahann

Ekosistem Pantai Studi Kasus di

Kawasan Segara Anakan Cilacap. Tesis pada Program Magister Perencanaan Kota dan Daerah. Program Pascasarjana Universitas Gadjah Mada, Yogyakarta.

Scoones I. 1999. New ecology and the social sciences: what prospects for a fruitful engagement? Annual Review of Anthropology 28: 479-507.

Walker, B. H., and D. A. Salt. 2006. Resilience Thinking: Sustaining Ecosystems and People in A Changing World. Island Press, Washington, D.C.,USA. 